\title{
Susanna Itäkare
}

\section{Pala taivasta, pala maata Englantilainen katolinen romaani 1900-luvulla}

\begin{abstract}
Kumoan käsitteen "katolinen kirjailija". Kardinaali Newman - - kiisti "katolisen" kirjallisuuden olemassaolon. Hän tunnusti vain sen mahdollisuuden, että tekstin uskonnollinen ulottuvuus voi ylittää sen kirjallisen ulottuvuuden. Hän kirjoitti, että kirjojen pitäisi käsitellä ensisijaisesti "langenneen ihmisen traagista kohtaloa". Olen samaa mieltä. "Inhimillinen tekijä" kiinnostaa minua, ei apologetiikka. - Graham Greene. (Allain 1983, 160; suom. SI.)

Greene luultavasti tulee englantilaisista kirjailijoista lähimmäksi sitä, mitä monet lukijat ja tutkijat pitävät tyypillisenä - ja mahdollisesti ainoana - katolisen romaanikirjailijan lajina (Whitehouse 1999, 27; suom. SI).
\end{abstract}

Kirjallisuudentutkimuksen esteettis-formalistinen paradigma on tunnetusti opettanut tutkijat suhtautumaan suurella varauksella kirjailijoiden kannanottoihin omista teoksistaan. Silti lainaukset hätkähdyttävät: kirjailija Graham Greene kyseenalaistaa koko (roomalais)katolisen ${ }^{1}$ romaanin (Catholic novel) lajikategorian, kun taas kirjallisuudentutkija J.C. Whitehouse nimeää kyseisen romaanin alalajin tyypillisimmäksi edustajaksi juuri Greenen.

Lausunnot voisi sivuuttaa kuriositeetteina, elleivät ne olisi osa laajempaa, itse asiassa jo 1800luvulla alkanutta keskustelua. ${ }^{2}$ On esim. kysytty, onko katolisen romaanin laji historiallisesti ja teoreettisesti mielekäs. Ajoittain katolinen romaani on jäänyt keskustelussa pelkäksi abstraktiksi käsitteeksi, jolla ei ole näyttänyt olevan paikkaa käytännön kirjallisuudentutkimuksessa.Toisaalta välillä havaintoja katolisesta romaanista on tehty taajaan. Ne ovat vaihdelleet epätarkoista kuvauksista preskriptiivisiin "totuuksiin" niin paljon, että on pakko parahtaa: mistä oikein puhumme, kun puhumme katolisesta romaanista? Monen tutkijan vastaus varsinkin 1900-luvun loppupuolella on ollut, että emme mistään eikä meidän tarvitsekaan, sillä koko kategoria on kirjallisuustieteellisesti aikansa elänyt (esim. Lodge 1986, 35-37; Whitehouse 1999, 13).

Näkemykseni mukaan katolisen romaanin lajikategoriaan kriittisesti suhtautuva asenne kumpuaa osittain postmodernismin ja jälkistrukturalismin epäluulosta kristinuskoa ja sen suurta kertomusta kohtaan. Jos Sana ja Totuus yritetään purkaa, on ymmärrettävää, että Kristus-uskoa esittävä katolinen romaanikategoria ei ole tavoiteltava. Lisäksi romaanilaji jo itsessään on historiallisesti osa länsimaiden sekularisaatioprosessia. Uskonnon aseman heikentyessä kirjallisuus on ominut sen monia ideologisia tehtäviä. Näin ollen katolisen romaanin laji on jo lähtökohdiltaan ristiriitainen. Esimerkiksi sopii sen ja klassisen realistisen romaanin suhde. Kumpikin pyrkii esittämään todellisuuden mahdollisimman kokonaisvaltaisesti ja autenttisesti, mutta molemmat käsittävät todellisuuden omalla tavallaan: klassinen realismi sulkeistaa kaiken yliluonnollisen, kun 
taas katolisuus näkee sen erottamattomaksi osaksi todellisuutta (Scott 1989, 50).

Toisaalta katolinen kirkkokaan ei ole pitkän historiansa aikana ollut kovin myötämielinen kirjallisuutta kohtaan. Kirkko on arvottanut taidetta pitkälti sen mukaan, miten uskollista se on kristilliselle mythokselle ja miten hyvin se on palvellut kirkon päämääria. Esimerkiksi Yhdysvalloissa termi "katolinen romaani" viittasi pitkään 1960-luvulle evankeliumia välittävään, didaktiseen käyttökirjallisuuteen, jonka kaunokirjallinen arvo oli kyseenalainen (Gandolfo 1992, xi-xii). Vasta 1900-luvun jälkipuolelta alkaen kirkko on alkanut suhtautua ennakkoluulottomammin myös sekulaariin kirjallisuuteen ja moderniin kulttuuriin. Tästä ovat osoituksena esimerkiksi Vatikaanin toisen kirkolliskokouksen pastoraalikonstituutio Gaudium et Spes (1965; suom. Kirkko nykymaailmassa) ja paavi Johannes Paavali II:n vuonna 1999 taiteilijoille osoittama kiertokirje.

Kirjallisuuden ja katolisuuden kompleksisesta suhteesta huolimatta osoitan tässä artikkelissa, että katolisen romaanin lajikategoria on kirjallisuushistoriallisesti mielekäs, mikäli laji määritellään tekstilähtöisesti ja tekstin geneerinen katolisuus ymmärretään sen sisäistekijän katolisen identiteetin kautta. Perustellakseni lajimääritelmäni esitän luennan Evelyn Waugh'n romaanista Brideshead Revisited (1945; suom. Mennyt maailma). Vaikka kirjallisuushistorioissa katolisen romaanitradition alkujuuret paikannetaan useimmiten 1800 -luvun puolivälin Ranskaan, ${ }^{3}$ keskityn tässä artikkelissa nimenomaan englantilaisen katolisen romaanin traditioon sen kultakaudella eli 1900-luvulla. ${ }^{4}$ Lajihan on levinnyt muuallekin, ennen kaikkea Yhdysvaltoihin.

Englannissa 1900-luvun kansalliskirjallisuuden kaanon sisältää useita teoksia, jotka on profiloitu nimenomaan katolisiksi, eturivissä tietenkin Waugh'n ja Greenen, mutta myös muun muassa Hilaire Bellocin ja Muriel Sparkin tuotannot. Vaikka suurin osa Englannin katolilaisista kuului 1900-luvun alkupuolella vähävaraiseen työväenluokkaan, englantilaiskatolinen kulttuurielämä oli koulutettujen, keski- ja yläluokkaisten käännynnäisten käsissä. Tätä elitististä osakulttuuria leimasi poliittinen, uskonnollinen ja kirjallinen konservatiivisuus. Kehitys oli ainakin osittain tulosta protestanttisesta reformaatiosta ja katolisuuden heikosta asemasta Englannissa 1800-luvun puoliväliin saakka. (Woodman 1991, 3-6; Parsons 1992, 179; Whitehouse 1999, 28.)

Luultavasti juuri katolisuuden vähemmistöstatuksesta johtuen Englannissa Vatikaanin toisen kirkolliskokouksen (1962-65) radikaalit uudistukset koettiin katolisessa yhteisössä voimakkaasti. Kirkolliskokous merkitsi uuden ajan suurinta muutosvaihetta (aggiornamento) katoliselle kirkolle. Mitään varsinaisia dogmaattisia muutoksia kokous ei kuitenkaan tehnyt; tarkoitus oli päinvastoin esittää vanhat totuudet uudella kielellä ja palata takaisin kristinuskon juurille. Kirkko alettiin ymmärtää monimuotoisena ja dynaamisena Jumalan kansana, joka on vuorovaikutuksessa koko muun yhteiskunnan kanssa. Virallisen valtahierarkian rinnalla korostettiin myös maallikoiden vastuunottoa uskonnollisista tulkinnoista ja moraalisista valinnoista. Kokous innoitti suuren merkityksen saaneita faktisia ja fiktiivisiä tekstejä, joissa konsiilia on tulkittu hyvin eri tavoin. (Woodman 1991, 36-43; Spencer 1996, 60-80; Dillon 1999, 45-53, 221-222.) Tähän prosessiin on osallistunut aktiivisesti katolisen romaanin traditiokin. Se on 1960-luvun 
lopulta lähtien monipuolistunut jopa siinä määrin, että aiempi, itsessään varsin kiistelty genrekategoria on uhannut murentua. Viime vuosikymmeninä onkin herännyt kysymys, miten pitkälle pluralismissa voidaan mennä, jotta yleensä kannattaa puhua katolisen romaanin genrestä.

Kysymystä katolisuuden ja sen esittämisen rajoista tematisoi David Lodgen menestysromaani How Far Can You Go? (1980), jota käsittelen artikkelini jälkipuolella. Luennan perusteella pyrin antamaan alustavan vastauksen siihen, onko 2000-luvulle tultaessa englantilaisen katolisen romaanin kohdalla parempi turvautua sielunmessuun vai korjaavaan, postmoderniin genremäärittelyyn (vrt. Whitehouse 1999, 11-14).

\section{Geneerinen katolinen identiteetti}

Koska katolisen romaanin lajia on pidetty ongelmallisena, erilaisia määritelmäyrityksiä on suorastaan tehtailtu. Useimmat ${ }^{5}$ niistä ovat tekijälähtöisiä keskittyen kirjailijan tunnustuskuntaan, uskoon ja intentioon. Samalla ne nojautuvat biografiseen metodiin ja mimeettiseen taidekäsitykseen (esim. Spencer 1996, 18). Tällöin teos on ennen kaikkea tekijänsä itseilmaisua, ja sen merkitys voidaan löytää hänen elämäänsä ja tuotantoaan tutkimalla.

Tekijän ominaisuuksien lisäksi lajin tutkimuksessa on ollut joskus tapana metsästää "olemuksellisesti" katolisia teemoja, joista esiin nousevat toistuvasti "neljä viimeistä asiaa" eli kuolema, viimeinen tuomio, taivas ja helvetti (Whitehouse 1999, 12). Brittiläistä katolista romaania määrittäviksi teemakokonaisuuksiksi Thomas Woodman nostaa katolisuuden tuottaman uskonnollisen, kulttuurisen ja sosiaalisen erilaisuuden, kirkon ja ympäröivän maailman suhteen ja hyvän ja pahan kysymyksen (1991; vrt. Spencer 1996, 57). En ole samaa mieltä Woodmanin kanssa: teemat eivät voi olla geneerisen luokittelun eksklusiivinen kriteeri, sillä se asettaisi genrelle liian normatiiviset ja mielivaltaiset rajat. Lisäksi esimerkiksi kysymystä hyvästä ja pahasta käsitellään useimmissa romaaneissa, ei pelkästän katolisuuden piirissä. Ian Ker huomauttaa, että teemat ja motiivit, jotka stereotyyppisesti usein liitetään katolisuuteen - esimerkiksi synti ja syyllisyys - eivät ole katolisen romaanin traditiossa lainkaan niin keskeisessä asemassa (2003, 203).

Genre ei ole pelkkä luokittelun väline, vaan se on myös teosten tuotantoa ja vastaanottoa säätelevä normisto (ks. Fowler 1982, 20-52). Geneeriset säännöt määräytyvät osittain historiallisesti teksteistä itsestään ja niiden sisältämistä muodollisista ja temaattisista piirteistä, mutta osin ne syntyvät tutkijan teoreettisen kategorisoinnin perusteella. Lähestyn omaa, tekstilähtöistä katolisen romaanin määritelmääni teemojen sijasta uskonnollisen taiteen ${ }^{6}$ väljän sateenvarjokäsitteen kautta. Sen yksi tärkeä alalaji on kristillinen taide kyseisen kategorian poliittisesta ongelmallisuudesta huolimatta. ${ }^{7}$ Kristillistä taidetta ja kaunokirjallisuutta järjestää sitoutuminen Kristususkoon siten kuin se Raamatussa ja traditiossa ilmoitetaan (ks. Hakala 2000, 9). Voidaan ajatella, että Kristus on Sana, Logos, johon kaikki muut tekstit ovat suhteessa. Kristus, Jumala ja ihminen, puolestaan sitoo tekstin niin transsendenssiin kuin immanenssiin.

Tekstin kristillisyys ei kuitenkaan ole mikään muuttumaton olemus, vaan se syntyy tekstin, lukijan ja kulttuurikontekstin yhtälön kautta. Liioin kristillisyys ei ole koskaan dominantti suhteessa 
tekstin poeettiseen funktioon. Mikäli näin on, ei voida puhua enää kauno-, vaan käyttökirjallisuudesta. (Emts. 16-21.)

Katolisen romaanin genre nähdään määritelmässäni kristillisen kaunokirjallisuuden omalakiseksi alalajiksi, jossa sitoutuminen Kristus-uskoon tapahtuu katolisen tradition ja opetusviran, magisteriumin kautta. Narratologisesti ilmaisten genremääritelmässä ratkaisevaa on teoksen sisäistekijän kokonaisvaltainen suuntautuminen ja sitoutuminen yhtäältä katoliseen maailmankuvaan ja toisaalta katolisesti ymmärrettyyn pyhään ja transsendenssiin. Kyse on siis tekstin identiteetistä, joka on sekä tiettyyn historialliseen instituutioon, kirkkoon, kuulumista että pyrkimystä vuorovaikutukseen pyhän, kolmiyhteisen Jumalan kanssa.

Tekstin suhteellisen vakaa ja eheä katolinen identiteetti ${ }^{8}$ kokoaa yhteen etenkin ennen Vatikaanin II kirkolliskokousta julkaistuja romaaneja. Tätä lajikategoriaa voidaan hyödyntää käytännön kirjallisuudentutkimuksessa aiempia paremmin. Englantilaisen katolisen romaanin kohdalla huomio kiinnittyy retrospektiivisesti ensiksi siihen, että uusi määritelmä sulkee pois suurehkon joukon teoksia, joiden status on aiemmin jäänyt auki. Tällaisia tapauksia ovat esimerkiksi Ford Madox Fordin ja Anthony Burgessin teokset. Vaikka yleisenä periaatteena kannattaisikin inklusiivisuutta, kirjallisen genren kohdalla rajaaminen tekee usein lajikategorian käyttökelpoisemmaksi. Toisaalta määritelmän avulla lajiin voidaan sisällyttää romaaneja, jotka aiemmin on jätetty siitä pois pelkästään sen vuoksi, että niiden tekijä ei ole katolilainen; esimerkkinä mainittakoon Iris Murdochin romaani Nuns and Soldiers (1980; suom. Nunnia ja sotilaita). Voidaan kuitenkin kysyä, tuoko määritelmäni mitään uutta sellaisten teosten kohdalla, jotka sen mukaan kuuluvat katolisen romaanin genreen ja jotka on laskettu lajin piiriin jo aikaisemmin. Tätä testaan Menneeseen maailmaan.

\section{Bridesheadin pyhä Sebastian}

--Sebastian sanoi yllättäen:

- Voi miten vaikeata on olla katolinen.

- Onko se jossakin suhteessa hyvin erilaista?

- On tietenkin. Kaikessa. (MM, 99.)

Evelyn Waugh'n romaani Mennyt maailma. Kapteeni Charles Ryderin hengellisetja maalliset muistelmat ${ }^{9}$ kiehtoo edelleen. Tarinaa ollaan muokkaamassa elokuvaksi. Toisaalta lukijat ja tutkijat ovat kiistelleet Menneen maailma tulkinnasta ja kaunokirjallisesta arvosta sen ilmestymisestä lähtien. Nykyiset näkemykset teoksesta on mahdollista jakaa karkeasti kahteen pääluokkaan. Joko Waugh'n teosta pidetään englantilaisen katolisen romaanin suurena klassikkona, jolloin se kertoo "jumalallisen armon toiminnasta erilaisten, mutta toisiinsa liittyvien henkilöhahmojen ryhmässä" (Waugh 1962, 7; suom. SI) tai sitten se nähdään homokirjallisuuden klassikkona, jossa huomio kiinnittyy Charles Ryderin ja lordi Sebastian Flyten homoeroottisen suhteen "'vastustamattomaan vetovoimaan '” (Hekanaho 2003, 34). Nämä kaksi luentatapaa suhtautuvat epä- 
luuloisesti toisiinsa, ja niitä on harvemmin edes yritetty yhdistää. ${ }^{10}$

Kummallakin tulkintatavalla on myös sisäiset ongelmansa. Pia Livia Hekanahon mukaan useiden homolukutapojen "ongelmana on kuitenkin modernin homoidentiteetin reflektoimaton sovittaminen Waugh'n fiktioon ja homoseksuaalisen halun ja tekojen yksivakainen liittäminen toisiinsa" (emts. 17). Katoliset luennat puolestaan nojautuvat usein uusplatoniseen, hierarkkiseen malliin kertoja-päähenkilö Charles Ryderin kolmesta rakkaudesta:

Bildungsroman -juoni viittaa Charlesin kehittymiseen ja kasvavaan kypsyyteen: hänen täytyy siirtyä Sebastiania kohtaan tuntemastaan kypsymättömästä ja vihjatusti homoseksuaalisesta rakkaudesta aikuiseen, mutta avioliiton ulkopuoliseen Julian rakastamiseen, ja lopulta Jumalan rakastamisen suomaan tyyneen tyydytykseen. (Kennedy 1990, 24; suom. SI.)

Romaanin keskeiseksi teemaksi onkin usein nostettu "ristiriita uskon pakottavien vaatimusten ja maallisten kiintymysten ja halujen yhtä polttavien vaateiden välillä" (emts. 36; suom. SI). Lopulta Jumalan rakkaus voittaa, ja Charles omaksuu katolisen uskon ja identiteetin, mikä tosin jää tekstissä vain muutaman hämärän viitteen varaan (esim. MM, 22, 388).

Hierarkkisen mallin suurin ongelma on, ettei sillä ole tarpeeksi selitysvoimaa, sillä se kuvastaa pikemminkin monin tavoin ymmärtämättömän Charlesin kuin sisäistekijän näkemystä. Romaanin tulkinnan kannalta on ensiarvoisen tärkeää huomata, että siinä kertojan ja sisäistekijän arvot ovat ristiriidassa keskenään. Vastenmieliseksi kuvattu, itsekeskeinen Charles ei ymmärrä sen paremmin itseään kuin muitakaan. Vasta tarinan lopussa hän tajuaa harvinaisen valaistumisen hetkellä olevansa "koditon, lapseton, keski-ikäinen, vailla rakkautta" (MM, 387; vrt. Hekanaho 2003, 14-15).

Monet tutkijat ovat huomioineet, että vaikka Charlesin muistelmien tarkoitus on osoittaa jumalallisen rakkauden ylivertaisuus inhimilliseen nähden, Mennyt maailma painottuu emotionaalisesti erittäin voimakkaasti Charlesin ja Sebastianin nuoruuden rakkauden nostalgiseen rekonstruointiin ja ylipäätään haluun ja sukupuoleen (Hekanaho 2003, 13, 34; Woods 1998, 258; Kennedy 1990, 24). Jos Waugh'n teoksen katolisessa luennassa keskitytään Jumalan rakkauteen ja sivuutetaan "maalliset" rakkaussuhteet korruptoituneina, ei romaanista jää analysoitavaksi oikeastaan mitäñ sillä jumalallinen rakkaus näyttäytyy siinä pääasiallisesti inhimillisen kautta. Täten romaanin erilaisia rakkauksia ei ole mielekästä asettaa hierarkkiseen suhteeseen, jossa pyyteettömän, jumalallisen agapen tehtävänä on syrjäyttää tai tuhota puutteesta syntyvä inhimillinen eros. Sen sijaan Mennyt maailma voidaan tulkita analogiamallin kautta, jossa rakennetaan synteesi arkitodellisuuden ja hengellisen järjestyksen, eroksen ja agapen välille (ks. Greeley 2000, 6-9). Mallia voi kutsua myös sakramentaaliseksi; katolisuudessahan sakramentit ovat konkreettisia merkkejä Jumalan läsnäolosta. Juuri sakramentaalisuus on keskiössä romaanin katolista identiteettiä konstruoitaessa.

Teoksessaan Like and Unlike God (1999) John Neary tutkii kaunokirjallisuutta analogisen 
ja dialektisen uskonnollisen imaginaation kautta. Jaottelu on alun perin teologi David Tracyn, mutta Neary lukee sitä lähinnä isä Andrew M. Greeleyn popularisoinnin välityksellä. Dialektinen malli korostaa hierarkkisia eroja ja niistä syntyvää ristiriitaa, kun taas analoginen malli painottaa vastaavuutta - ei kuitenkaan samuutta - esimerkiksi ihmisen ja Jumalan välillä. Nearyn mukaan Greeley yksinkertaistaa liikaa samastaessaan dialektisen mallin protestanttisen ajattelun kanssa ja analogisen katolisuuden kanssa. Silti lienee selvää, että katolisen kirkon sakramenttikeskeisyys kumpuaa analogisesta imaginaatiosta pyhän ja maailman, hengen ja materian välillä, kun taas protestanttinen raamattukeskeisyys erottaa Sanan inhimillisestä maailmasta. (Neary 1999, 9-10; vrt. Greeley 2000, 1-2, 5.)

Menneen maailman sentimentaalis-realistisessa diskurssissa analoginen, sakramentaalinen malli näyttäytyy ennen kaikkea sen ainoassa varauksettoman pyhänä esitetyssä hahmossa, Marchmainin perheen nuorimmassa pojassa Sebastianissa. Palatessaan keski-ikäisenä muistoihinsa 1920-luvun Oxfordiin Charles kuvailee silloista ystäväänsä, nuorta Sebastiania ylimaallisen kauniiksi, hyväsydämiseksi ja rakastavaksi. Näin kuvattuna Sebastian edustaa ihmiskunnan täydellistä alkutilaa ennen syntiinlankeemusta vetäen varautuneen Charlesinkin mukaansa "suljettuun ja lumottuun puutarhaan" (MM, 37; vrt. Woods 1998, 258-259). Kuvaukset miesten yhteisestä kesästä Bridesheadin linnassa viittaavat niin Genesiksen luomiskertomukseen, Laulujen lauluun kuin myöhempään pastoraaliperinteeseen (esim. MM, 91-92). Niissä rakkaus yhdistää hengen ja materian; vaikka linna on kiveä ja kiinni maassa, jopa kivisydäminen Charles kokee olevansa "hyvin lähellä taivasta" (MM, 91).

Paratiisi ei ole kuitenkaan ikuinen. Sebastianin nopea vajoaminen alkoholismiin ja masennukseen ja sitä seuraava miesten välirikko eivät kuvasta niinkään Sebastianin omaa syntiinlankeemusta, vaan Charlesin karkotusta paratiisista rakkauden puutteen vuoksi. Charles ei nimittäin pysty hyväksymään ystäväänsä sellaisena kuin tämä on, vaan yhdessä Sebastianin äidin, tekopyhän uskovaisen karikatyyriksi kuvatun Lady Marchmainin kanssa, haluaa holhota ja muuttaa häntä (vrt. Spencer 1996, 33-34; Higdon 1994, 83). Kumpikin haluaa leikkiä jumalaa suhteessa Sebastianiin ja tehdä hänestä oman luomuksensa. Tällöin he epäonnistuvat testeistä tärkeimmässä, rakkaudessa ja menettävät Sebastianin.

Sebastian katoaa Marokkoon ja lyöttäytyy yhteen entisen muukalaislegioonalaisen, saksalaisen Kurtin kanssa. Alkoholisoitunutta ja sairasta Kurtia hoitava, itsekin vakavasti sairas Sebastian on "todellinen laupias samarialainen" (MM, 242) ja pyhimys, joka antaa itsensä lahjaksi toiselle. Ei liene sattumaa, että hän on 200-luvulla eläneen roomalaisen sotilaan, pyhän Sebastianin kaima, josta on pitkän ikonografisen ja kirjallisen tradition kuluessa tullut myös epävirallinen homoseksuaalien suojeluspyhimys (ks. Kaye 1996). Kurtin kuoleman jälkeen Sebastian päätyy tunisialaisen munkkiluostarin juopottelevaksi, mutta rakastetuksi ulkojäseneksi. Katolisissa Mennyt maailma -luennoissa on korostettu sairaan Sebastianin katumusta ja paluuta äitikirkon helmaan (Hekanaho 2003, 34). Tällöin tulkitsijat ovat kiinnittäneet hänen uuteen uskonnolliseen elämäänsä homoseksuaalisuudesta luopumisen merkityksiä. Toisaalta miehen kohtalo on nähty päinvastaisesti myös alennustilana, joka on seurausta hänen syntisestä elämästään. 
Pidän näitä tulkintoja perusteettomina. Kristillisessä mielessä on kyseenalaista väittää, että Sebastian olisi hurskaampi munkkien luona asuessaan kuin yrittäessään pelastaa Kurtia saksalaisilta vankileireiltä. Samoin oletus, että Sebastian olisi luostarissa jollakin tavoin tukahduttanut homoseksuaalisuutensa, ei saa tukea romaanista. Tosin selibaatissa hän todennäköisesti elää, joten romaanista on vaikea konstruoida myöskään yksiselitteistä homoseksuaalisuuden ”vapauttamisen" viestiä.

Väitän, että Sebastian esitetään sekä homona että pyhänä niin romaanin alussa kuin lopussa (vrt. Ker 2003, 185-186), eikä hänellä ole tarvetta radikaaliin muuttumiseen. Pyhyys on tässä itsensä antamista ehdoitta Jumalalle sellaisena kuin on, ei itsepetosta tai minuuden tukahduttamista. Toisin kuin esimerkiksi siskonsa Julia, Sebastian ei missään vaiheessa hylkää uskoaan tai varsinaisesti edes kirkkoa. Itse asiassa hän toteaa uskovansa mukisematta "kaiken" (MM, 100) mitä kirkko opettaa. Uskontososiologisesti ilmaisten hän on näin paremminkin uskonopin kuluttaja kuin tuottaja (ks. Dillon 1999, 26-27, 254), mikä on sopusoinnussa magisteriumin kanssa.

Monien henkilöiden silmissä Sebastian on juoppona ja sairaana homona pelkkä hylkiö (ks. Hekanaho 2003, 32), mutta Jumala (ja tekstin sisäistekijä) näkee hänet toisin, kuten veljensä Tunisiassa tavannut Cordelia kertoo Charlesille: "Olen nähnyt muita hänen kaltaisiaan, ja uskon, että he ovat hyvin lähellä Jumalaa ja hyvin rakkaita hänelle" (MM, 343).

Perinteisessä katolisessa diskurssissa (esim. pyhimyselämäkerroissa) subjekti on se, joka kärsii kuin Kristus. Sebastian onkin tässä redusoitavissa Dostojevskilta ja katolisesta kirjallisuudesta tutun pyhän syntisen kärsivään hahmoon (ks. Sharrock 1984, 88-89). On kuitenkin huomioitava, että Sebastianin synnit ovat muiden olettamia, eikä kirkko pidä sen enempää alkoholismia kuin homoseksuaalista suuntautumistakaan sinällään syntinä. ${ }^{11}$ Sebastianin pyhittää ennen kaikkea hänen jättäytymisensä Jumalan armon varaan ja siitä kumpuava rakkautensa, joka toistaa Jumalan intohimoista rakkautta luomakuntaansa. Täten juuri Sebastian on Menneen maailman katolisen identiteetin temaattinen manifestaatio. Hänessä henki ja materia, pyhä ja maailma, rakkaus ja kärsimys yhdistyvät tavalla, joka on syvästi sakramentaalinen ja katolinen. Tällöin romaanin katolisuus etääntyy Lady Marchmainin ja Charlesin uskonkäsityksestä, joka rakentuu ensisijaisesti moraalisääntöjen varaan.

\section{Siiman nykäisy}

Menneessä maailmassa katolinen sakramentaalisuus on hyvin kirkollista, vaikka henkilöhahmona Sebastian toki on maallikko. Katolisuudessa kirkko jakaa pappiensa välityksellä sakramentteja, näin myös Waugh'n romaanissa. Siinä papit esiintyvät vain pienessä sivuroolissa, mutta heidän merkityksensä on suuri (vrt. Spencer 1996, 40-42). He ovat "Jumalan käsityöläisiä", joiden käsissä on sielujen pelastus (vrt. Ker 2003, 186-188). Cordelia esimerkiksi visioi Sebastianille hyvän katolisen kuoleman: "Ja sitten hänet jonakin aamuna taas sellaisen juopotteluretken jälkeen löydetään portilta henkihieverissä, ja vain silmäluomien värähdys osoittaa hänen saadessaan viimeistä voitelua, että hän on tajuissaan” (MM, 343). Kukaan katolinen henkilöhahmo ei teoksessa 
kyseenalaista pappien erityisasemaa Kristuksen edustajina maan päällä.

Menneessä maailmassa henkilöhahmojen katolinen identiteetti on myönteinen vastaus jumalalliseen kutsuun. Se syntyy vähittäin kirkon elämään osallistumisen ja uskon, toivon ja rakkauden kasvamisen kautta, missä sakramenteilla on keskeinen osuus. Kaikki Menneen maailman keskeiset henkilöhahmot palaavat tai liittyvät katoliseen kirkkoon tarinan kuluessa. Kyseessä on englantilaiselle katoliselle romaanille tyypilliseen tapaan "esi-isien usko"12 (ks. MM, 249) ja Jumalan toiminta maan päällä erityisesti kirkon kautta. Jumalan näkymätön siima päästää ihmisen "vaeltamaan vaikka maailman ääriin, mutta kuitenkin tuo hänet takaisin yhdellä nykäyksellä" (MM, 250), kuten Cordelia G.K. Chestertonin "The Queer Feet" -dekkaritarinaa (1911; suom. "Kummalliset jalat") lainaten toteaa. Jumala näyttäytyykin usein Vatikaani II:ta edeltävissä romaaneissa metsästäjänä tai kalastajana, joka ei päästä uhrejaan pakoon (Spencer 1996, 50; vrt. Pearce 1999, 236). Siiman tavoin Menneen maailman sisäistekijän katolinen, sakramenttikeskeinen identiteetti on näkymätön ja helppo sivuuttaa, mutta romaanin kokonaisvaltainen ymmärtäminen on vaikeaa ilman sitä. Sama pätee muiden Waugh'n katolisten teosten (ennen kaikkea romaanitrilogia The Sword of Honour 1966) lisäksi esimerkiksi Greenen useisiin romaaneihin ${ }^{13}$ (ks. Woodman 1991, 29-30).

Toisaalta Waugh'n ja Vatikaanin 50-luvulla jopa harhaoppiseksi syyttämän Greenen teosten ristiriitaiset lukemisperinteet muistuttavat, että kaunokirjallinen teksti on väistämättä mahdoton palauttaa yksiselitteiseksi uskonnolliseksi tai muuta ideologiaa välittäväksi viestiksi. En esitäkään, että Vatikaanin toista konsiilia edeltävä katolisen romaanin traditio olisi aina tiukan "oikeauskoista" tai että poeettisen funktion dominoima, monikollinen teksti ylipäätään edes voisi olla ideologisesti täysin ristiriidaton. Kirkkoa voidaan toki katolisessa romaanissa kritisoida ja sitä vastaan voidaan kapinoida rajusti, mutta silti se jätetään paikalleen hengellisenä auktoriteettina. Samalla tekstin homogeeninen katolinen identiteetti säilyy.

Uudemmassa katolisessa kirjallisuudessa sen sijaan kirkon halutaan muuttuvan maailman mukana, ja sen valtahierarkian yksinoikeus opin tulkintaan kyseenalaistetaan (Dillon 1999, 910). Aikaisempi valtahierarkian legitimoima kiinteä identiteetti - henkilöhahmojen ja koko tekstin - voidaan kokea suojaavan sijasta yhdenmukaisuuteen pakottavaksi haarniskaksi (ks. Lassila 1996, 147). Haarniska on siis ollut olemassa "aina", mutta vasta tietyssä historiallisessa tilanteessa se on mahdollista julkisesti kyseenalaistaa ja jopa riisua. Muutoksen airuena englantilaisessa kirjallisuudessa on usein pidetty Greenen romaania A Burnt-out Case (1961), mutta varsinaisesti Vatikaani II:ta ja sen aikaansaamia muutoksia käsittelee vasta Lodgen How Far Can You Go? (ks. Woodman 1991, 92-95; Spencer 1996, 195).

\section{Papista hipiksi}

Kirjallisuudentutkija ja kirjailija David Lodgen romaani How Far Can You Go? kertoo kymmenen akateemisen katolilaisen elämänvaiheista vuodesta 1952 aina 1970-luvun loppuun saakka lähinnä Lontoossa ja sen ympäristössä. Tuona aikana päähenkilöt muuttuvat kirkolle kuuliaisista 
nuorista opiskelijoista keskenään hyvin erilaisiksi aikuisiksi, joiden katolisuutta on mahdotonta enää mahduttaa yhden identiteettihaarniskan sisään.

Katolisuus on usein stereotyyppisesti liitetty seksuaalisuuteen ja sen kontrolloimiseen. Joskus Lodgen romaanikin on nähty pelkäksi kuvaukseksi seksuaalimoraalin ja -käytäntöjen muuttumisesta toisen maailmansodan ja Vatikaani II:n jälkeisessä englantilaiskatolisessa kulttuurissa (Parsons 1992). Silti How Far Can You Go? -romaanin otsikon esittämä kysymys viittaa paremminkin katolisen identiteetin ja romaanitradition säilyttämiseen muutosten kourissa (Spencer 1992, 198).

Kirkolliskokouksen muutokset koskettivat kirkon metafyysistä järjestystä, "ihmeellisen monimutkaista ja kekseliästä teologian, kosmologian ja kasuistiikan synteesiä, joka sijoitti yksittäiset sielut hengelliselle Käärmeet ja tikapuut -pelilaudalle, motivoi niitä yhtä suurilla annoksilla toivoa ja pelkoa ja lupasi niille ikuisen palkinnon, jos ne pysyivät mukana pelissä" (HF, 239). ${ }^{14}$ Näin romaanissa toteaa anonyymi ääni "Katolilaiset Avoimen Kirkon Puolesta" -uudistusryhmän (Catholics for an Open Church, $C O C^{15}$ ) pääsiäisjuhlilta vuonna 1975 kuvatulla nauhalla. Kirkolliskokouksen vaikutuksesta sielulle varman paikan - joko kohti taivasta tai helvettiä - tarjonneen metafyysisen pelin absoluuttinen ja universaali asema kyseenalaistui. Samoin käy niin Lodgen teoksen henkilöhahmojen kuin koko romaanin katoliselle identiteetille. Henkilöhahmoista keskityn kahteen, pappiin ja maallikkomieheen.

Tarinan alussa isä Austin Brierley esitetään hurskaana seurakuntapappina, joka on salaa ihastunut "seksikkääseen viettelijättäreen" (HF, 14), opiskelijatyttö Pollyyn. Brierley saapuu yllättäen nuorten pyhän Valentinuksen juhliin ja keskeyttää Pollyn eroottishenkisen tanssiesityksen. Pappi nuhtelee nuoria, sillä "katolisten opiskelijoiden pitäisi olla esimerkkinä muille nuorille mielen ja ruumiin puhtaudessa" (HF, 27). Tässä siis katolista identiteettiä rakennetaan seksuaalisen puritaanisuuden varaan. Brierley on kuitenkin itse vaarassa rikkoa asettamansa normin tunnustaessaan myöhemmin kirkkoherralle, että hänellä on epäpuhtaita ajatuksia Pollysta. Kirkkoherran kainostelematon vastaus on jo selkeä rikkomus Brierleyn puhtoista identiteettipolitiikkaa vastaan. "Oletko kokeillut siemensyöksyjä?" (HF, 29), vanhempi pappi kysyy nuoremmalta, joka ei edes ymmärrä kysymystä.

Myöhemmin isä Brierley pääsee sapattivapaalle opiskelemaan. Hän valitsee eksegetiikan ja aloittaa oman "miten pitkälle voi mennä" -matkansa. Uudet relativistiset tulkinnat evankeliumien keskeisistä tapahtumista korostavat niiden symbolista merkitystä historiallisen autenttisuuden sijasta. Pappi kokee magisteriumia horjuttavan eksegeettisen vallankumouksen ja alkaa seurakuntaan palattuaan jakaa uusia oppeja saarnoissaan, mikä johtaa hänet pitkään konfliktiin konservatiivien kanssa. Kompromissina piispa suostuu päästämään Brierleyn opiskelemaan psykologiaa. Samalla pappi osallistuu salaa COC -liikkeen toimintaan. Isä kutsutaan kotona pidettäviin agape -kokoontumisiin. Solidaarista yhteisöllisyyttä korostavat rakkaudenateriat ovat osa 60-70 -lukujen hippi-ideologiaa, mutta teologisesti ne ovat varhaiskristillisyydessän̈ suorastaan vallankumouksellisia. Kertojan kuvaama uudistusryhmä on etääntynyt jo hyvin kauaksi kirkon opetuksesta. Toisaalta juuri kirkolliskokous on antanut sen muotoutumiselle alkusysäyksen. Kirkolliskokous 
mahdollistaa myös isä Brierleyn sakramentti- ja pappiskäsityksen radikaalin uudelleen määrittelyn. Itse asiassa koko hänen näkemyksensä kirkosta ja sen tulevaisuudesta on muuttunut:

Kirkon varhaisimmassa vaiheessa Herran ehtoollisen viettämistä ei ollut rajoitettu pappeuteen, ja Austin (kuten he nyt kutsuivat isä Brierleytä) itse totesi että ajatus erityisluokasta, jolle oli annettu yksinoikeus sakramenttien viettämiseen, oli nopeasti jäämässä pois käytöstä. Hän ennusti ajan, jolloin koko huolellisesti laadittu piispojen ja pappien ja hiippakuntien ja seurakuntien rakenne häviäisi, kotiehtoolliset korvaisivat seurakunnan sunnuntaimessun nimettömän, valtavan väenpaljouden, ja jolloin keskinäinen ohjaus ja tiedostamisryhmät korvaisivat ripin ja vahvistuksen sakramentin. (HF, 142.)

Austinin papiksi vihkimisen sakramentin kyseenalaistavat pohdinnat merkitsevät väistämättä myös hänen oman katolisen pappisidentiteettinsä muutosta ja vakavaa uskon kriisiä. Hän hylkää papillisen pukeutumisen ja omaksuu hippityylin partoineen kaikkineen. Ajattelussaan hän ei enää nojaudu pelkästään kirkon magisteriumiin, vaan lukee modernia teologiaa, filosofiaa ja psykologiaa. Austin yrittää muodostaa lukemansa pohjalta yhdenmukaisen jumalakuvan siinä kuitenkaan onnistumatta. Romaanin päättävässä pääsiäisjuhlan kuvauksessa hän näyttää silti päässeen tyydyttävään käsitykseen kirkosta ja uskosta. Hänelle kristinusko on nyt ennen kaikkea Kristuksen perustama vallankumousliike järjestäytyneen uskonnollisen instituution sijasta. Ristiinnaulitseminen ja varsinkin ylösnousemus ovat hänelle metaforia, eivät historiallisia tosiasioita, jolloin myös uskonnon yliluonnollinen aspekti on mahdollisesti pelkkää inhimillistä kielenkäyttöä ilman referenssiä. (HF, 230-231.) Tämä ei kuitenkaan merkitse keskeisistä katolisista symboleista luopumista, vaan vain niiden uudelleen määrittelyä: "käsitteet muuttuvat kun tieto muuttuu" (HF, 136; vrt. Dillon 1999, 203-206).

Pian pääsiäsjuhlan jälkeen Austin jättää lukemattomien muiden miesten esimerkkiä seuraten pappeuden ja perustaa perheen. Viimeinen, mitä kerrotaan uskontososiologista väitöskirjaa valmistelevasta Austinista, on hänen uskonnollinen identiteettinsä: "Hän pitää itseään yhä jollakin tavoin katolilaisena, mutta osittain tutkimusintresseistään johtuen hän käy joka sunnuntai eri kirkossa tai kappelissa - vuorotellen katolisessa, anglikaanisessa, ortodoksisessa, vapaakirkollisessa ja kveekareiden kokoushuoneella” (HF, 242). 1950-luvulla katolisessa kirkossa toisen kirkkokunnan palvelukseen osallistuminen oli vakava synti, josta piti ripittäytyä. Austinin katolisuus on kombinaatio järkeä, uskoa ja vallan desentralisaatiota (ks. Dillon 1999, 190). Se luo yhteyksiä sen sijaan, että tuottaisi mitän stabiilia identiteettihaarniskaa, joka erottaa meidät muista (ks. emts. 74-76, Woodman 1991, 93-94).

How Far Can You Go? -romaanissa katolisuuden nopea muuttuminen hämmentää lähes kaikkia henkilöhahmoja. Silti useimmat heistä kannattavat, tuottavat ja haluaisivat lisää muutoksia (ks. Spencer 1996, 205). Ainoa romaanin konservatiivi on kaunis Miles, katolisuuteen kääntynyt Cambridge-tutkija, johon kirkon liturgia vetoaa etenkin esteettisesti ja emotionaalisesti. 


\section{Katolisen dandyn valinta}

Opiskelija Miles rakentaa 50-luvulla katolista identiteettiä, joka on hyvin lähellä Mark D. Jordanin hahmottelemaa katolista dandya homomiehen legitiiminä sosiaalisena roolivaihtoehtona. Yleensä dandya määrittää sosiaalisessa mielessä ylipukeutuminen. Katolisella dandylla normatiivinen pukeutuminen ulottuu kuitenkin paljon pintaa syvemmälle. Hän "pukeutuu" heteroseksistiseen ortodoksiaan tai jopa fundamentalismiin päästäkseen turvaan homoeroottisilta tunteiltaan. Dandyt liittyvätkin kaikkein konservatiivisimpiin katolisiin (mies)järjestöihin ensisijaisesti siksi, että ne takaavat heille hetero- tai aseksuaalisen tulevaisuuden. (Jordan 2000, 220-225; vrt. Dillon 1999, 161-162.) Rippi-isältään Miles saa ohjeeksi rukoilla ja olla kärsivällinen kiinnostuakseen tytöistä, mutta itse hän haaveilee pitkään pappeudesta nimenomaan voidakseen luopua ongelmallisesta seksistä (HF, 26).

Viimein vuosikausia seksuaali-identiteetin ja katolisuuden ristipaineessa pyristellyt Miles päätyy katolisen psykiatrin vastaanotolle. Lääkärin neuvo kertoo traditionaalisen katolisuuden ja 60-lukulaisen seksuaalipolitiikan välisestä ristiriidasta: "Useiden istuntojen jälkeen psykiatri sanoi: 'En voi tehdä hyväksesi mitään. Lääkärinä neuvon sinua hankkimaan kumppanin. Katolilaisena voin ainoastaan sanoa: kanna ristisi.” (HF, 138.)

Istunnot ovat käännekohta, jonka myötä Miles vakuuttuu homoseksuaalisuutensa pysyvyydestä. Silti hän tekee vielä yhden epätoivoisen yrityksen säilyttää katolinen dandy-identiteetti. Hän menee pääsiäisenä luostariin retriittiin ja jopa harkitsee hakeutumista kokelaaksi kyseiseen yhteisöön. Kävelyretkellä nuori veli Bernard yllättäen kysyy masentuneelta Milesilta, onko tämä " gay" kehottaen miestä hyväksymään itsensä ja olemaan ylpeä itsestään (HF, 173). Bernard on ensimmäinen Milesin kohtaama henkilö, jossa katolinen usko kohtaa ääneen lausutun homoseksuaalisuuden. Veli ei ole katolinen dandy, vaan katolinen homo. Kun kertoja seuraavan kerran mainitsee Milesin, tämä on opiskelutoverin mukaan tullut ulos kaapista ja asuu yhdessä kumppaninsa, kyseisen Bernardin kanssa. Angelan ihmetellessä voivatko katolilaisetkin olla homoseksuaalisesti aktiivisia, Michael vastaa venyttäen Vatikaani II:n henkeä yhä pitemmälle: “’No, virallisesti he eivät tietenkään voi' , /---/'mutta luulisin että myös he voivat päättää seurata omaatuntoaan, kuten me ehkäisyn kanssa. Tai kuten opiskelijat, jotka harrastavat esiaviollista seksiä. "” (HF, 199.)

Milesille Vatikaani II näyttäytyy halpahintaisena protestanttisuutena, jonka liturgiset ja taiteelliset uudistukset tekevät katolisuudesta rumaa ja naurettavaa. Katolinen sakramentaalisuus on saanut väistyä dialektisen imaginaation tieltä. Ulostulostaan huolimatta Miles onkin yhä opillisesti konservatiivinen dandy (HF, 231). Hän ei halua rakkaudenaterioita ja ekumeniaa, vaan yksiselitteisiä vastauksia ja rajojen kautta selkeän ja turvallisen identiteetin. Hänen kaltaisilleen ei kuitenkaan näytä löytyvän luontevaa paikkaa vapaamieliseksi kutsutussa uudistuneessa kirkossa. Tämä on jossakin määrin yllättävää: pluralistinen, avoin yhteisö ei ole sittenkään tarpeeksi emansipatorinen sisällyttääkseen ongelmattomasti muut kuin heterot. Ei olekaan ihme, että Miles kokee kirkon pettäneen hänet. vastuun jokaisen omalletunnolle. 
How Far Can You Go?-romaanissa uskonnollisesta identiteetistä on tullut antiessentialistinen konstruktio (ks. Pulkkinen 1998, 160-163, 200-202). Ihminen ei ole enää deterministisesti "paavinuskoinen" kasteesta hautaan, vaan hänellä on vaihtoehtoisia tapoja olla katolilainen ja muutenkin mahdollisuus "identiteettishoppailla" melko laajasti. Tätä suhteellista, individualistista vapautta ei kuitenkaan esitetä positiivisessa valossa, vaan se on kova hinta, joka haarniskaidentiteetin riisumisesta pitää maksaa. Mileskin turvautuu Valiumiin joutuessaan seuraamaan, miten hänen tuntemansa katolinen kirkko on nopeasti katoamassa (HF, 137-138). Lopulta hän jättää kirkon, koska kokee, että kirkko ja sen myötä hän itse on menettänyt spesifin katolisen identiteetin: "Miles on yhä Cambridgessa, mutta on palannut takaisin anglikaaniseen kirkkoon, koska hänen mukaansa anglikaanisen ja roomalaiskatolisen uskon välillä ei näytä olevan suurta eroa, ja hän pitää enemmän edellisen liturgiasta” (HF, 243).

Dorothy Spencerin mukaan Milesin ratkaisu pelastaa samalla Lodgen romaanin vaatimukselta mennä pitemmälle vaikeaksi koetun katolisen homokysymyksen kohdalla (1996, 204205). Silti Bernardin utooppista gay Catholic -hahmoa voi pitää sisäistekijän vahvana poliittisena kannanottona homoseksuaalisuuden puolesta. Toisaalta Miles on synkempi hahmo kuin sielunveljensä Waugh'n Sebastian. Klassisen traagisen homohahmon tavoin Miles ei löydä henkistä ja hengellistä kotia mistään, kun taas Sebastian löytää turvapaikan miesten selibaattiyhteisöstä. Sebastianin ei tarvitse missän vaiheessa kyseenalaistaa vakaata kirkkoa tai olemuksellista identiteettiään sen jäsenenä. Liioin hänen ei tarvitse verhoutua katolisen dandyn oikeauskoiseen kaapuun, sillä homoseksuaalisuutta ei hänen ympäristössään vielä nimetä ja nähdä niin suureksi uhkaksi katoliselle identiteetille kuin 50-luvulla. Sebastian jääkin 40-luvun homoesityksenä eräänlaiseen välitilaan välttäen Milesin hahmon traagisuuden, mutta olematta tietenkään Bernardin kaltainen, Vatikaani II:n jälkeinen emansipoitu homokatolilainenkaan.

\section{Miten pitkälle voi mennä?}

How Far Can You Go? on tietoinen asemastaan englantilaisen katolisen romaanin traditiossa. Kertomuksen alussa nuoret henkilöhahmot puhuvat arvostavasti Greenen ja Waugh'n teoksista ja ovat ylpeitä heidän asemastaan kirjallisuusinstituutiossa, mikä antaa vahvistusta heidän omallekin katoliselle identiteetilleen. Tarinassa palataan toistuvasti Greenen tuotantoon, joka muuttui 60-luvulla epäortodoksisemmaksi. Aluksi muutos hämmentää englannin opiskelija Michaelia, ja hän on huolissaan kirjailijan uskon puolesta. Myöhemmin hän huomaa irrottautuneensa Waugh'n kiivaasti puolustamasta antimodernista katolisuudesta ja tulleensa lähelle progressiivista Greenea (HF, 82). Tämän jälkeen Greenea tai Waugh'ta ei romaanissa enää mainita. Hiljaisuuden voi tulkita Lodgen teoksen irrottautumiseksi aiemmasta traditiosta, jolle se toisaalta on jo osoittanut avoimesti kunniavelkansa. ${ }^{16}$

Edeltäjistään How Far Can You Go? poikkeaa ensinnäkin aiheeltaan ja osin teemoiltaan (Spencer 1996, 56-57, 269-270). Eniten Lodgen teos eroaa edeltävästä traditiosta kuitenkin postmodernin kerrontansa suhteen (vrt. Parsons 1992, 183-185). Ironisen, kriittisen ja meta- 
fiktiivisen kerronnan kautta institutionaaliseen katolisuuteen otetaan romaanissa voimakkaasti etäisyyttä. Menneen maailmankin kertoja Charles on tosin lapsuudessaan oppinut, että "kristinuskon peruskertomukset oli jo kauan sitten osoitettu myyteiksi" (MM, 98). Charles kokee kuitenkin kääntymyksen ja korottaa katolisuuden Totuudeksi muiden diskurssien yläpuolelle, mikä on myös sisäistekijän näkemys. Lodgen teoksessa näin ei käy, vaan koko yhden totuuden ja suurten kertomusten mahdollisuus pyritään siinä purkamaan (vrt. Dillon 1999, 206; Greeley 2000, 173-188).

Lodgen kerronnallisilla konventioilla leikittelevä kertoja on viehtynyt narratiiviseen teologiaan ja kiinnittää yleisönsä huomion yhtäältä kaunokirjallisuuden ja toisaalta uskonnollisten tekstien ja ylipäätään uskontojen samankaltaiseen luonteeseen: ne kaikki ovat tarinoita, joilla on tietyt konventionsa. How Far Can You Go? tekstualisoi, suhteellistaa ja sekularisoi katolisuutta. Tämä esitetään avoimena ja monimutkaisena prosessina, jonka lopputuloksesta ei ole mitään varmuutta. Tällöin romaaniin on vaikeaa tuottaa sisäistekijää, joka olisi sitoutunut selvärajaiseen katoliseen maailmankuvaan ja suuntautuisi kohti transsendenssia.

Katolisuus ei voi enää olla geneerisen luokittelun väline, jos se on menettänyt kulttuurisen identiteettinsä ja mukautunut niin ympäröivään maailmaan, hahmottomaan "yleiskristillisyyteen" kuin niitä kaikkia tuottavaan postmoderniin tekstuaalisuuteen. Silti voidaan väittāä, että Lodgen romaani on kyllä katolinen, mutta katolisuutta ja identiteettiä tekstin kaikilla tasoilla jatkuvasti purkavalla ja rakentavalla tavalla. Tällöin katolisuus hahmottuu ennen kaikkea kulttuuriseksi, dynaamiseksi tuotannoksi. Se ei enää jäsenny tuottava valtaeliitti/vastaanottava "massa" -jaottelun kautta, vaan siinä kaikki osapuolet osallistuvat uskonnollis-kulttuuristen merkitysten tuottamiseen vallan epäsuhtaisesta jakautumisesta huolimatta. (Dillon 1999, 24-31, 254-255.) Katolisia identiteettejä ei puolestaan "postmodernin dekonstruktion nimissä hajoteta, dekonstruktio ei ole destruktiota. Kyse on identiteettien rakentumisen näyttämisestä ja kieltäytymisestä asettamasta niille perustahakuisesti pohjaa." (Pulkkinen 1998, 154.) Näin Lodgen teosta voi kutsua esimerkiksi Sara Maitlandin The Virgin Territory -romaanin (1984), Michael Carsonin Sucking Sherbet Lemons -romaanin (1988) ja Lodgen myöhemmän tuotannon (esim. Paradise News 1991; suom. Paratiisin uutiset) tavoin postkatoliseksi.

Tästä kirjallisesta kehityksestä huolimatta osa Vatikaani II:n jälkeen ilmestyneistä katolisista romaaneista rakentaa yhä perinteisen katolisen sisäistekijän, joka ei problematisoi sen enempää katolisen kirkon statusta absoluuttisena hengellisenä auktoriteettina kuin siitä kumpuavaa yksiselitteistä maailmankuvaakaan. Silti Woodmanin mukaan uuskonservatiivisilla romaaneilla, kuten ei myöskään postkatolisilla, ole suurta merkitystä lajin tulevaisuuden kannalta, vaan se tullee yhdistymään ekumeeniseen diskurssiin. (1991, 159-160, 164.)

Woodmanista poiketen en näe romaanilajin sukupuuttoon kuolemista väistämättömänä. Liioin en halua tehdä geneeristä jakoa uuskonservatiivisen romaanin ja uudistusmielisen, lodgelaisen romaanin välille, vaan kutsun molempia postkatolisiksi. Kumpikin ilmiö on seurausta Vatikaanin II:n kirkolliskokouksesta. Lisäksi niihin ovat vaikuttaneet myös muut yhteiskunnalliset ja kulttuuriset muutokset, kirjallisuusteoreettisia muutoksia (esim. jälkistrukturalismi, su- 
kupuoliteoria) unohtamatta. Kirjallisuus ei suinkaan passiivisesti heijasta näitä muutoksia, vaan käyttää niitä materiaalinaan ja myös tuottaa niitä. Se, että katoliseksi romaaniksi voidaan laskea niin Readin patriarkaaliset moraalitarinat kuin Maitlandin radikaalifeministinen romaani kertoo katolisen kulttuurin nykyisestä moniarvoisuudesta.

Postkatolisen romaanin genre kokoaa yhteen tekstejä, joita yhdistää kiinteän identiteetin sijasta väljä tyylillinen, wittgensteinlainen perheyhtäläisyys. Käytännössä yhdistävänä tekijänä on usein eksplisiittinen identiteettipoliittinen keskustelu ja vielä useammin Kristus-usko. Postkatoliset teokset eivät silti välttämättä jaa mitään kaikille yhteistä piirrettä, ”mutta ne jakavat useita piirteitä osittain ja muodostavat eroille ja muutoksille avoimen kokonaisuuden samalla lailla kuin suku tai perhe" (Heinämaa 1996, 159).

Postkatolisen romaanin genremääritelmä on täten erittäin avoin, eikä laji varmasti olisi tarpeeksi "taivaallinen" esimerkiksi Waugh'n vanhoilliskatoliseen makuun. Uudemmassa katolisessa kirjallisuudessa transsendenssin ja kirkon hierarkian sijasta tai rinnalla ollaan usein kiinnostuneita maailmasta ja maallikoista, esimerkiksi yhteiskunnallisesta oikeudenmukaisuudesta ja ekologisista kysymyksistä. Silti voidaan kysyä, eikö juuri analoginen, maailman tosissaan ottava ajattelu ole hyvinkin katolista ja leimallista nimenomaan katolisen romaanin traditiolle, vaikkapa Waugh'n omalle Menneelle maailmalle. Tällöin uuden postkatolisen romaanin post-etuliite ei tarkoita välirikkoa aiemman perinteen kanssa, vaan loogista jatkumoa ja eteenpäin kehittelyä kirkollisen ja kirjallisen paradigman vaihdoksen kautta (vrt. Dillon 1999, 255-256). Sanalla sanoen: tästä voidaan mennä vielä pitkälle.

Kiitokset Marja-Liisa Linderille lähdeteosten lainaamisesta ja Tapani Rytöhongalle käsikirjoituksen kriittisestä lukemisesta.

\section{Viitteet}

${ }^{1}$ Katolisuus viittaa tässä laajasti läntiseen kirkkokuntaan, joka tunnustaa paavin Pietarin seuraajaksi. Vaikka arkikielessä katolisuus samastetaan roomalaiskatolisuuteen, jälkimmäinen on vain yksi katolisen kirkon monista osakirkoista eli riituksista.

${ }^{2}$ Kardinaali John Henry Newman väittää esseessään "Catholic Literature in the English Tongue, 1854-8” (1859), että katolinen kirjallisuus on mahdottomuus reformaation jälkeisessä Englannissa. Newman kuitenkin sivuuttaa tärkeitä 1500- ja 1600-luvun englantilaiskatolisia runoilijoita, kuten Robert Southwellin, Richard Crashaw'n ja John Drydenin. Ian Kerin mukaan englantilainen kirjallisuus ei olekaan aivan niin protestanttista kuin Newman väittää edes ennen katolisen romaanin nousua, jonka alkupisteen Ker ajoittaa vuoteen 1845 eli kirjailijanakin tunnetun Newmanin kääntymiseen. (Ker 2003, 1-7.)

${ }^{3}$ Ranskalaisen katolisen romaanin historiasta ks. Griffiths 1966; Scott 1989.

${ }^{4}$ Englantilaisen katolisen romaanin historiasta ks. Woodman 1991; Spencer 1996; Pearce 1999; Ker 2003, $1-12$.

${ }^{5}$ Esim. Woodman 1991, xi-xii; Labrie 1997, ix; Ker 2003, 8. Ainoita tekstilähtöisiä katolisen romaanin määritelmiä on Anita Gandolfon, jonka mukaan amerikkalaista katolista romaania määrittää "kokemus katolilaisena olemisesta Yhdysvalloissa” (1992, xii; suom. SI). Jää epäselväksi, kenen kokemuksesta Gandolfo puhuu, ja miksi juuri kokemuksen epistemologia on niin keskeinen katolisen romaanin 
genressä.

${ }^{6}$ Teoksessaan Uskonto elokuvassa (1979) Matti Paloheimo määrittelee Friedrich Heileriin nojautuen uskonnon yliluonnolliseksi koettuun pyhään eli mysteeriin kohdistuvaksi palvonnaksi ja antautumiseksi (emts.

11). Tässä valossa uskonnollisen elokuvan ja yleensä taiteen määritelmäksi muotoutuu: ”(V)oinemme märïitellä uskonnolliseksi elokuvaksi elokuvan, jonka perusulottuvuus on suuntautuminen tai sitoutuminen tuonpuoleiseen, pyhään. Sen sijaan uskonnollisen elokuvan ei tarvitse kuvata uskontoa, uskonnollista kulttia tai käyttäytymistä - - .” (Emts. 11; kursiivi alkutekstissä.)

${ }^{7}$ Kristillisen kaunokirjallisuuden mahdollisuudesta ja määrittelemistä on keskusteltu 1950-luvulta lähtien etenkin Yhdysvalloissa (ks. Hakala 2000, 2). Paloheimo sen sijaan kiistää koko kristillisen taiteen mahdollisuuden viittaamalla Jumalan inkarnaatioon, jossa raja sakraalin ja maallisen välillä kumoutuu. Taide ei näin voi itsessään olla pyhää, vaan se voi vain esittää pyhää. (1979, 14-18.) Itse kuitenkin ajattelen kirjailija Ron Hansenin tavoin, että kirjallisuus voi toimia kristillisenä sakramenttina eli pyhänä merkkinä, jossa ihminen ja Jumala kohtaavat (Hansen 2002, 3). Silti on syytä huomioida Paloheimon varoitus, että kristillisen taiteen kategoriasta tulee helposti vallankäytön väline, jolla mitataan yksittäisen tekstin "oikeauskoisuus" ja sitä kautta sen arvo $(1979,18)$.

${ }^{8}$ Vatikaanin toista kirkolliskokousta edeltävä identiteetti näyttäytyy vakaana, universaalina ja sisäiset erot kieltävänä, sillä sen vankaksi perustaksi valetaan kirkon autoritaarinen opetusvirka (vrt. Pulkkinen 1998, 140-143, 163). Perinteinen katolinen romaanikin esittää identiteetin kokemuksena minuuden ykseydestä, eheydestä ja aitoudesta.

${ }^{9}$ Mennyt maailma -luentani perustuu osittain esitelmääni "Saint Sebastian at Brideshead. Spirituality and Sexuality in Evelyn Waugh's Brideshead Revisited (1945). - Evelyn Waugh Centenary Conference. Hertford College, University of Oxford, 24.-27.9.2003.

${ }^{10}$ Toisaalta teoksen status niin katolisena romaanina kuin homoromaanina on toistuvasti kyseenalaistettu. Edmund Wilsonin kritiikistä The New Yorker -lehdessä (1946) lähtien monet kriitikot ja tutkijat ovat esittäneet, että Menneen maailman katolisuus on pelkkää eliittiklubiin kuulumista tai yritystä palata lapsuuden paratiisiin (Kennedy 1990). Gregory Woodsin mukaan Waugh'n teos on heteroseksuaalinen romaani, jossa tosin esitetään myös homoseksuaalisuutta (1998, 257; vrt. Higdon 1994, 77, 86-87; Pitcher 2003).

${ }^{11}$ Vatikaanin uskonopin kongregaatio julkaisi v. 1986 dokumentin Letter to the Bishops of the Catholic Church on the Pastoral Care of Homosexual Persons, jossa homoseksuaalinen suuntautuminen erotetaan selkeästi homoseksuaalisista teoista. Suuntautuminen nähdään dokumentissa moraalisesti neutraaliksi, mutta se johtaa helposti homoseksuaaliseen aktiivisuuteen, joka puolestaan on Jumalan luoman järjestyksen vastaista ja siten syntiä.

${ }^{12}$ Ilmaisu on lainaus tunnetusta englantilaisesta virrestä (Spencer 22n19). Englantilaista katolista kulttuuria on leimannut jännite yhtäältä eksoottisen vierauden ja toisaalta katolisuuden englantilaiskansallisen erityisyyden välillä. Menneessä maailmassa katolisen menneisyyden nostalgisointi on myös osa romaanin modernin kritiikkiä. (Woodman 1991, 50-60.)

${ }^{13}$ Näistä voidaan mainita esim. Kiveä kovempi (1938), Voima ja kunnia (1940), Mutta suurin

kaikista...(1948) ja Jutun loppu (1951).

${ }^{14}$ Romaanin suomennokset ovat omiani.

${ }^{15}$ Ei ole sattumaa, että lyhenne COC viittaa myös e-pilleriin (Combined Oral Contaceptive); Lodgen romaanissa progressiivinen maallikkoliike ajaa mm. katolilaisten oikeutta ehkäisyyn (Spencer 1996, 200). ${ }^{16}$ Mennyt maailma on puolestaan velkaa useille aikaisemmille katolisille romaaneille, mm. Robert Hugh Bensonin, Maurice Baringin ja Compton Mackenzien katolisuutta, aristokratiaa ja yliopistoelämää yhdistäville teoksille (Pearce 1999, 35, 163, 236-237). 


\section{Lähteet}

\section{Kaunokirjallisuus}

LODGE, DAVID 1993 (1980): How Far Can You Go? London: Secker \& Warburg. (=HF) WAUGH, EVELYN 1962 (1945): Brideshead Revisited. The Sacred and Profane Memories of Captain Charles Ryder. London: Penguin Books.

WAUGH, EVELYN 1982 (1945): Mennyt maailma. Kapteeni Charles Ryderin hengelliset ja maalliset muistelmat. Romaani. Suomennos Pentti Lehtinen. (Alkuteos Brideshead Revisited. The Sacred and Profane Memories of Captain Charles Ryder.) Kolmas painos. Helsinki: Kustannusosakeyhtiö Otava. (=MM)

\section{Tutkimuskirjallisuus}

allain, Marie-françoise 1983 (1981): The Other Man. Conversations with Graham Greene. Translated from the French by Guido Waldman. (Alkuteos L'autre et son double.) London, Sydney, Toronto: The Bodley Head.

Dillon, Michele 1999: Catholic Identity. Balancing Reason, Faith, and Power. Cambridge: Cambridge University Press.

FOWLER, ALASTAIR 1982: Kinds of Literature. An Introduction to the Theory of Genres and Modes. Oxford: Clarendon Press.

gandolfo, anita 1992: Testing the Faith. The New Catholic Fiction in America. New York; Westport, Connecticut: London; Greenwood Press.

GREeley, ANDrew 2000: The Catholic Imagination. Berkeley, Los Angeles, London: University of California Press.

GRIFFITHS, RICHARD 1966: The Reactionary Revolution. The Catholic Revival in French Literature 1870-1914. London: Constable.

HAKALA, TYTTI 2000: Kaunokirjallisuuden kristillisyys Bo Giertzin Stengrunden kristillisenä romaanina. Painamaton pro gradu -opinnäyte. Taiteiden tutkimuksen laitos, yleinen kirjallisuustiede. Helsinki; Helsingin yliopisto.

HANSen, ron 2002 (2001): A Stay Against Confusion. Essays on Faith and Fiction. New York: Perennial (HarperCollins).

HeINÄMAa, SARA 1996: Ele, tyyli ja sukupuoli. Merleau-Pontyn ja Beauvoirin ruumiinfenomenologia ja sen merkitys sukupuolikysymykselle. Helsinki: Gaudeamus.

HeKANAHo, PIA LIVIA 2003: "Minä en ole minä, sinä et ole hän, he eivät ole heitä." Mieheyden representaatiot Evelyn Waugh'n romaanissa Mennyt maailma. - Ruumiillisuus. Kirjallisuudentutkijain Seuran vuosikirja 55. Toimittaneet Sanna Karkulehto ja Ilmari Leppihalme. Helsinki: Suomalaisen Kirjallisuuden Seura. 12-43. 
HIGDON, DAVIS LEON 1994: Gay Sebastian and Cheerful Charles: Homoeroticism in Waugh's "Brideshead Revisited". - ARIEL: A Review of International English Literature. 25:4. 77-89.

Jordan, Mark D. 2000: The Silence of Sodom. Homosexuality in Modern Catholicism. Chicago and London: The University of Chicago Press.

KAYE, RICHARD A. 1996: Losing his religion. Saint Sebastian as contemporary gay martyr. - Outlooks. Lesbian and Gay Sexualities and Visual Cultures. Edited by Peter Horne and Reina Lewis. London and New York: Routledge. 86-105.

KenNedy, valerie 1990: Evelyn Waugh's “Brideshead Revisited”: Paradise Lost or Paradise Regained? - ARIEL: A Review of International English Literature. 21:1. 23-39.

KER, IAN 2003: The Catholic Revival in English Literature, 1845 - 1961: Newman, Hopkins, Belloc, Chesterton, Greene, Waugh. Leominster: Gracewing.

LABrie, ross 1997: The Catholic Imagination in American Literature. Columbia and London: University of Missouri Press.

LASSILA, ANNA 1996: Tutut roolit, tuntemattomat alueet. Butch, femme ja identiteettipolitiikan dekonstruktio. - Uusin silmin. Lesbinen katse kulttuuriin. Toimittaneet Pia Livia Hekanaho - Kati Mustola - Anna Lassila - Marja Suhonen. Helsinki: Yliopistopaino. 139-162.

LODGE, DAVID 1986: Write On. Occasional Essays '65- '85. London: Secker \& Warburg.

NEARY, JOHN 1999: Like and Unlike God. Religious Imaginations in Modern and Contemporary Fiction. Atlanta, Georgia: Scholars Press.

PALOHeIMO, MATTI 1979: Uskonto elokuvassa. Helsinki: Kirjapaja.

parsons, gerald 1992: Paradigm or Period Piece? David Lodge's How Far Can You Go? In Perspective. - Journal of Literature \& Theology. 6:2. 171-179.

PEARCE, JOSEPh 1999: Literary Converts. Spiritual Inspiration in an Age of Unbelief. London: HarperCollins.

Pitcher, JONATHAn 2003: Brideshead Remodernized. - Evelyn Waugh Newsletter and Studies. Autumn 2003. www.lhup.edu/jwilson3/Newsletter_34.2.htm

pUlKkinen, tuija 1998 (1996): Postmoderni politiikan filosofia. (Alkuperäisversio: The Postmodern and the Political Agency.) Helsinki: Gaudeamus.

scott, malcolm 1989: The Struggle for the Soul of the French Novel. French Catholic and Realist Novelists, 1850 - 1970. Houndmills, Basingstoke, Hampshire and London: Macmillan.

SHARrock, ROGER 1984: Saints, Sinners and Comedians. The Novels of Graham Greene. Notre Dame, Indiana; University of Notre Dame Press/Turnbridge Wells, Kent: Burns \& Oates.

SPENCER, DOROTHY 1996: The Second Vatican Council and the English Catholic Novel. Liverpool: University of Liverpool.

whitehouse, J. c. 1999: Vertical Man. The Human Being in the Catholic Novels of Graham Greene, Sigrid Undset, and Georges Bernanos. London: Saint Austin Press.

woodman, thomas 1991: Faithful Fictions. The Catholic Novel in British Literature. Milton Keynes, Philadelphia: Open University Press. 